\title{
DIREITO À CIDADE E DIREITO À FELICIDADE: CONSIDERAÇÕES EMPÍRICAS ${ }^{1}$
}

\section{RIGHT TO CITY AND RIGHT TO HAPPINESS: EMPIRICAL CONSIDERATIONS}

\section{Alessandra Danielle Carneiro dos Santos Hilário² \\ Duina Porto ${ }^{3}$}

\begin{abstract}
"O sol nasce e ilumina as pedras evoluídas Que cresceram com a força de pedreiros suicidas

Cavaleiros circulam vigiando as pessoas Não importa se são ruins, nem importa se são boas

E a cidade se apresenta centro das ambições Para mendigos ou ricos e outras armações Coletivos, automóveis, motos e metrôs Trabalhadores, patrões, policiais, camelôs

A cidade não pára, a cidade só cresce O de cima sobe e o de baixo desce..."

(Trecho da música "A Cidade", de Chico Science e Nação Zumbi)
\end{abstract}

\section{Resumo}

O artigo aborda as relações entre o Direito à Cidade e o Direito à Felicidade, partindo de construções teóricas para desenvolver a análise empírica pelos métodos analítico quantitativo, qualitativo e dedutivo, por meio de indicadores (Índice de Desenvolvimento Humano - IDH; e Índice de Desenvolvimento Humano Municipal - IDHM) cotejados com o levantamento bibliográfico, os quais mensuram a efetivação de Direitos Sociais, Econômicos e Culturais (DESC) no espaço urbano, a fim de verificar o grau de desenvolvimento humano de municípios tomados como amostragem e sua relação com a média de desenvolvimento nacional. A par dessa análise, importantes considerações são extraídas nas relações entre DESC, desenvolvimento, felicidade e liberdade, a indicar, com fundamento empírico, que há uma relação intrínseca, mas variável, entre desenvolvimento humano e efetivação de DESC no espaço urbano, cujo foco é o usufruto de recursos e bens de vida digna nesse contexto. No

\footnotetext{
${ }^{1}$ Artigo escrito em parceria pelas autoras, a partir da junção das ideias desenvolvidas nos respectivos artigos anteriores intitulados "O Direito à Cidade nas Relações entre o Direito do e o Direito ao Desenvolvimento: Problemas de Efetivação" e "A Felicidade como Elemento Indicador de Desenvolvimento Social", ambos aceitos para apresentação no XXIII Congresso Nacional do CONPEDI/UFPB. No presente ensaio, o diferencial foi a inserção das considerações empíricas a partir dos elementos teóricos apresentados.

2 Professora Assistente do Departamento de Ciências Jurídicas de Santa Rita/PB/CCJ/UFPB, na área de Direito Constitucional e Administrativo. Doutoranda em Direitos Humanos e Desenvolvimento pelo Programa de Pós- Graduação em Ciências Jurídicas do Centro de Ciências Jurídicas da UFPB. Email: alesandrahilario@ccj.ufpb.br.

${ }^{3}$ Professora Assistente do Departamento de Ciências Jurídicas de Santa Rita/PB/CCJ/UFPB, na área de Direito Processual Civil. Doutoranda em Direitos Humanos e Desenvolvimento pelo Programa de PósGraduação em Ciências Jurídicas do Centro de Ciências Jurídicas da UFPB. Email: duinaporto@hotmail.com.
} 
entanto, por ser relação cambiante, nem sempre crescimento econômico importará, necessariamente, em desenvolvimento humano adequado e felicidade, mormente quando o pressuposto teórico e empírico são elementos como capacitação (liberdade de escolha e aptidão para viabilizar transformações), democracia e desigualdade. Nesse viés, é determinante a coalizão Estado/Sociedade capacitada e atuante como protagonistas do processo de desenvolvimento humano adequado.

Palavras-chave: Direito à Cidade; Felicidade; Desenvolvimento; Efetividade; Dignidade

\section{Abstract}

The article deals with the relationship between Right to the City and Right to Happiness, starting from theoretical constructions to develop empirical analysis by quantitative, qualitative and deductive methods, through indicators (Human Development Index - HDI / Human Development Index Municipal - IDHM), which are compared with bibliographical survey, which measure the implementation of Economic, Social and Cultural Rights (ESCR) in urban space, in order to verify the degree of human development of municipalities taken as sampling and their relation with the average Development. Along with this analysis, important considerations are drawn in the relationships between ESCR, development, happiness and freedom, to indicate empirically that there is an intrinsic but variable relationship between human development and realization of ESCR in urban space, whose goal is the enjoyment of resources and assets of a dignified life in this context. However, because it is a changing relationship, not always economic growth will necessarily matter in adequate human development and happiness, especially when theoretical and empirical presupposition are elements such as empowerment (choice freedom and ability to make transformations viable), democracy and inequality. In this bias, State / Society coalition is determinant and active as protagonists of the process of adequate human development.

Keywords: Right to the City; Happiness; Development; Effectiveness; Dignity

\section{INTRODUÇÃO}

O propósito deste ensaio é realizar um cotejo entre o Direito à Cidade e o Direito à Felicidade como institutos convergentes e complementares, a partir de concepções teóricas desses institutos, objetivando realçar as aproximações que os unem e que têm como foco central a liberdade e o desenvolvimento. Nesse sentido, com o intuito de extrair análises concretas a partir dos fundamentos teóricos expostos, foi realizada uma pesquisa empírica a partir de indicadores mundialmente adotados e aceitos como suficientes à mensuração de graus de desenvolvimento como consentâneos da efetivação de Direitos Sociais, Econômicos e Culturais no locus urbano, com consequente ampliação para a análise do Direito à Felicidade nesse contexto. 
Em vista disso, o item 2 trata sobre a concepção do Direito à Cidade e suas interfaces com o próprio conceito de desenvolvimento, realçando as contradições que podem abranger o crescimento econômico restrito e o próprio desenvolvimento humano e plural. No cerne dessas questões, a liberdade é enfocada como elemento preponderante à consecução do Direito à Cidade e do próprio desenvolvimento.

O item 3 enfoca, assim, a Felicidade como direito, de concepção fluida ou aberta (por ser subjetiva), mas que guarda relação intrínseca com o Direito à Cidade, dado que o locus urbano é o espaço físico em que o indivíduo se realiza enquanto pessoa digna, e com o Desenvolvimento compreendido como direito humano plural e inalienável. Nesse sentido, há uma linha intercessora que aglutina o Direito à Cidade, a felicidade e o desenvolvimento, todos envoltos pelo manto da liberdade.

Por fim, as considerações empíricas inicialmente apontadas como designação metodológica instrumental a este ensaio, encontram-se referidas no item 4. A amostragem tomou como base três municípios brasileiros, os quais ocupam, respectivamente, o primeiro, o quingentésimo quinquagésimo sétimo e último lugares (5565) no ranking de IDH 2010, a fim de analisar, pelas diferentes ordens, o impacto da efetivação desses DESC na cidade para mensuração de desenvolvimento e felicidade. O IDH e IDH-M são indicadores estatísticos, respectivamente, Índice de Desenvolvimento Humano e IDH Municipal, que são obtidos a partir de dados relativos à saúde, educação, rendimento e outros elementos que ensejam a verificação do nível de desenvolvimento humano, que varia entre muito baixo a muito elevado. O objetivo foi analisar a relação dos dados estatísticos com a mensuração do nível de desenvolvimento e a dialética entre crescimento econômico, vida digna, felicidade e desenvolvimento.

\section{Direito à cidade e direito ao desenvolvimento: concepções e interfaces}

É instrumental e basilar para o objeto deste ensaio a concepção clara acerca das devidas diferenciações e definições sobre a cidade, o urbano e o Direito à Cidade. Expoente vanguardista nessa matéria é o francês Henri Lefevbre, que enveredou a sua análise na perspectiva da sociologia urbana. Em vista disso, percebe-se uma linha divisória entre o que se entende por cidade e por urbano, expressão cunhada por Lefevbre (2001, p. 46), assim, a cidade seria expressão relacionada a uma perspectiva mais material, concernente à sua paisagem e formas arquitetônicas e o urbano seria a relação dialética, imaterial, bem 
característica com a sociedade que nela se insere, de natureza mutuamente interferente, influenciando e sendo influenciada pela cidade, em áreas diversas: pequenos grupos (famílias e corporações) e grandes grupos (Estado, Igreja e sociedade) em contato com a cultura e as leis.

Nesse sentido, a cidade seria uma obra (e não um produto) resultante de ações humanas sequenciadas por essas relações e, por isso não poderia ser tida como mercadoria (BAVA, 2013, p. 4-5) destinada à comercialização, não obstante Lefevbre não subestime a ação do poder de mercado sobre a mesma. Não se olvide, entretanto, que mesmo o aspecto material da cidade, para Lefevbre, admite significados que os podem identificar com a própria ideologia e configuração da cidade, ou seja, as próprias estruturas arquitetônicas retratam o aspecto urbano da cidade e as relações (inclusive de poder) entre os seus atores: indivíduos, grupos, Estado e Mercado (2005, p. 62-63). Arrematando o tema (cidade e urbano), Lefevbre propõe a definição de cidade em visão mais ampliada, conjugando as acepções acima destacadas, como a projeção da sociedade sobre um local, a partir de um conjunto de padrões definidos, bem como de leis gerais paralelamente a especificidades de cada cidade.

Feitas as devidas conceituações, destaque-se o processo de urbanização nesse contexto, a fim de, mais a frente, abordar-se o Direito à Cidade, com o qual guarda íntima relação. Para Lefevbre, o processo de urbanização das cidades tem início em conjunto com o processo de industrialização. O "ponto zero" seria a ausência completa e absoluta de qualquer item/suporte urbano na cidade, quando se sobressaía os elementos rurais caracteristicamente de produção. Desta feita, o processo de industrialização é o responsável pelas novas configurações da cidade (e sua relação com o campo - urbano x rural), assim como o causador dos problemas nela vivenciados no tocante ao seu crescimento desordenado e modo de viver, tornando-se o ponto de atração de riquezas, conhecimento, técnicas e obras ${ }^{4}$ (LEFEVBRE, 2005, p. 3).

Como consequência dessa relação simbiótica ${ }^{5}$ de causa e efeito e interações constantes, a cidade admite duas vertentes: a cidade como obra, ou seja, com valor de uso; e a cidade como produto, isto é, com valor de troca. Nessa última análise de Lefevbre encontra-se a origem da concepção contemporânea bem delineada por David Harvey de cidade como mercadoria (HARVEY, 2013). Para Lefevbre, esse processo de industrialização significou o início da fase do capitalismo, entendido como o modelo de regência da vida econômica nas cidades,

\footnotetext{
${ }^{4}$ Obra, para Lefevbre, assume o significado de resultado das ações humanas.

${ }^{5}$ Toma-se de empréstimo a simbiose como um dos tipos de relações entre duas espécies que se aliam ou se conjugam para ambas galgarem dado benefício, entretanto de forma desproporcional.
} 
ressaltando, então, o seu valor de troca (e não de uso) e pontuando, em um marco temporal e histórico, o começo da crise nas cidades, não obstante um período progressivo de explosão e proliferação de centros urbanos, permeados por ações voltadas à manutenção do poder econômico, cujos grupos dispunham soluções aos problemas urbanos sob a ótica deste regime de mercado, inclusive em associação com o Estado.

Sim, esta cidade que atravessa tantas vicissitudes e metamorfoses, desde seus núcleos arcaicos que seguiram de perto a aldeia, essa forma social admirável, essa obra por excelência das práxis e da civilização se desfaz e se refaz sob nossos olhos. [...] quando emergiram os problemas de conjunto, sob o nome de urbanismo, foram eles subordinados à organização geral da indústria. Atacada ao mesmo tempo por cima e por baixo, a cidade se alinha pela empresa industrial; figura na planificação como engrenagem; torna-se dispositivo material próprio para se organizar a produção, para controlar a vida quotidiana dos produtores e o consumo dos produtos. Rebaixada para o nível de meio, ela estende a programação para o lado dos consumidores e do consumo; serve para regulamentar, para ajustar uma sobre a outra, a produção das mercadorias e a destruição dos produtos através da atividade devoradora chamada 'consumo'. (LEFEVBRE, 2005, p. 76).

Nesse ponto, o autor ressalta a descaracterização da cidade em seu aspecto imaterial, de sentimento de pertencimento, e que produziu a "miséria mental e social", destituindo a sociedade da socialização, posto que absortos nos aparatos/recursos que a industrialização e o capitalismo trouxeram, ensimesmados. Ao passo que os grupos privados se apossaram dos ônus/misteres estatais em troca das compensações econômicas, agudizando a dinâmica valor de uso $\mathrm{x}$ valor de troca e intensificando os problemas oriundos de todo esse processo urbanístico.

Este momento vai até a implosão-explosão das violências latentes sob as terríveis coações de uma racionalidade que se identifica com o absurdo. Desta situação nasce uma contradição crítica: tendência para a destruição da cidade, tendência para a intensificação do urbano e da problemática urbana. (LEFEVBRE, 2005, p. 79).

David Harvey contextualiza bem essa problemática, destacando o caso da urbanização de Paris, que teve como pressuposto a grande crise econômica de 1848 em razão do desemprego alarmante e do não reinvestimento do capital, dos quais resultaram movimentos sociais de trabalhadores e burgueses insatisfeitos. A solução apontada por Haussmann ${ }^{6}$ foi

\footnotetext{
${ }^{6}$ Georges-Eugène Haussmann foi um advogado, funcionário público, político e administrador francês. Nomeado prefeito de Paris por Napoleão III, tinha o título de Barão e foi o grande remodelador de Paris, cuidando do planejamento da cidade, durante 17 anos, com a colaboração de arquitetos e engenheiros renomados de Paris na época. Haussmann planejou uma nova cidade, modificando parques parisienses e criando outros, construindo vários edifícios públicos, como a L'Opéra. Melhorou também o sistema de distribuição de água e criou a grande rede de esgotos, quando em 1861 iniciou a instalação dos esgotos
} 
deliberadamente a urbanização para a reaplicação dos lucros e geração de emprego, clarificando que a ratio não estava, em sua essência, no compromisso com o bem-estar coletivo e nem como um ideal de cidade e desenvolvimento, porém divorciado das aspirações sociais, significou um processo urbano em larga escala levado a cabo através da associação com instituições financeiras de crédito (solvendo o destino do lucro) e que produziu profundas alterações no modo de viver do parisiense, entretanto os resultados dessas estratégias foram percebidos após 15 anos.

O sistema funcionou muito bem por uns quinze anos, e envolveu não só a transformação da infraestrutura urbana como também a construção de um novo modo de vida e uma nova personalidade urbana. Paris tornouse a Cidade Luz, o grande centro de consumo, turismo e prazer; os cafés, as lojas de departamentos, a indústria da moda, as grandes exposições tudo isso modificou a vida urbana de modo que ela pudesse absorver o dinheiro e as mercadorias, por meio do consumismo. Mas foi então que o sistema financeiro especulativo e as instituições de crédito superdimensionadas quebraram, em 1868. Haussmann foi demitido; Napoleão III, em desespero, foi à guerra contra a Alemanha de Bismarck e saiu derrotado. No vácuo que se seguiu surgiu a Comuna de Paris, um dos maiores episódios revolucionários da história do capitalismo urbano nascida, em parte, de uma nostalgia daquele mundo que Haussmann tinha destruído, e do desejo de retomar a cidade por parte dos que se viram despossuídos pelas obras que ele impôs. (HARVEY, 2013).

Assim, a industrialização e o processo de urbanização, os mesmos se constituem no pano de fundo, no cenário no qual se erigirá o Direito à Cidade, como um pressuposto jurídicoteórico ao desenvolvimento harmônico e concatenado à compreensão da interface desse Direito com o Direito do e ao Desenvolvimento.

Nesse sentido, Lefevbre vincula o Direito à Cidade às necessidades sociais, não individualmente tomadas como potencialidade de consumo isolado e seletivo de produtos e bens, mas que transcende essa individualidade tomando proporções coletivas e difusas,

entre La Villette e Les Halles, supervisionada pelo engenheiro Belgrand. [...] O Barão de Haussmann foi encarregado pelo novo imperador de modernizar a cidade. Para isto, o Barão demoliu as antigas ruas, pequenos comércios e moradias da cidade e criou uma capital ordenada sobre a geometria de grandes avenidas e bulevares, uma nova disposição que também iria colaborar com o fim dos levantes populares (grifo nosso), as barricadas de Paris. Auteil, distrito vizinho anexado, passou a ser subúrbio como outros. O plano criado para o centro da cidade, previa a reformulação da área em um dos extremos dos ChampsElysées (Campos Elíseos). Haussmann criou uma estrela de 12 avenidas amplas em volta do Arco do Triunfo, onde grandes mansões foram erguidas entre 1860 e 1868 sobre os escombros da antiga cidade. [...] O prédio [L'Opéra de Paris ] é suntuoso e singular, uma mistura de materiais como pedra, bronze, mármore e outros, bem como de estilos que vão do clássico ao barroco, tido como o "estilo do 2 은 Império". Haussmann foi sub-prefeito em Nérac em 1830, prefeito do Sena de 1853 a 1870, senador em 1870, deputado em 1877. As despesas decorrentes de todas as suas obras provocaram protestos e levaram à sua demissão em 1870 (grifo nosso). Disponível em: http://pt.wikipedia.org/wiki/GeorgesEug\%C3\%A8ne_Haussmann. Acesso em 30 jul 2014. 
referindo-se a um sentimento de solidariedade preocupado com um bem-estar geral no presente e no futuro.

A cidade, assim, é o objeto, como óbvio, do Direito à Cidade, direcionando os seus estudos acerca do espaço urbano e suas implicações socioeconômicas, políticas e culturais, alvejando, em todo o caso, a construção de um locus que distribui, pelo menos de forma aproximada, equitativa e qualitativamente os recursos necessários à fruição dos direitos sociais ${ }^{7}$ nesse território como fonte de realização de vida e como pressuposto do desenvolvimento como direito fundamental humano, conforme Flávia Piovesan (PIOVESAN, 2004, p.22). Corroborando o entendimento sobre o objeto do Direito à Cidade, afirma categoricamente Lefevbre:

Trata-se da necessidade de uma atividade criadora, de obra (e não apenas de produtos e de bens materiais consumíveis), necessidades de informação, de simbolismo, de imaginário, de atividades lúdicas. [...] Enfim, a necessidade da cidade e da vida urbana só se exprime livremente nas perspectivas que tentam aqui se isolar e abrir os horizontes. As necessidades urbanas específicas não seriam necessidade de lugares qualificados, lugares de simultaneidade e de encontros, lugares onde a troca não seria tomada pelo valor da troca, pelo comércio e pelo lucro? Não seria também a necessidade de um tempo desses encontros, dessas trocas? (LEFEVBRE, 2005, pp. 103-104).

Arrematando a compreensão sobre o Direito à Cidade e correlacionando-o com o sistema de Direitos Constitucionais Fundamentais Humanos insertos na Constituição Federal do Brasil de 1988, na doutrina e jurisprudências constitucionais, é capitulado como um direito de terceira dimensão, pois transcende individualidade do ser humano, revestindo-se de um direito para as gerações presentes e futuras e que importa em preocupações para além do espectro individual egoístico.

É um direito que envolve, de forma cumulativa e não geracional (SARLET, 2006, P. $293)^{8}$, a proteção de direitos individuais civis e políticos e direitos sociais em sua amplitude (econômicos, culturais e ambientais), de forma progressiva no locus urbano em que o indivíduo se insere. Ressalte-se que o Direito à Cidade, não obstante, em 1901, Henri Lefevbre o tenha

\footnotetext{
7 Circunscrevemo-nos a referir apenas os direitos sociais em virtude da concordância com o entendimento de Flávia Piovesan acerca da necessária efetividade dos direitos individuais como pressuposto à efetividade dos direitos sociais, pelo que ambos se revelam indissociáveis dentro da categoria de dimensões de direitos fundamentais. Ver: PIOVESAN, Flávia. Direitos sociais, econômicos e culturais e direitos civis e políticos. SUR - Revista Internacional dos Direitos Humanos. Ano I, Número I, 2004, p. 22.

8 Filiamo-nos ao entendimento de Ingo Wolfgang Sarlet acerca de uma categorização dos Direitos Fundamentais em dimensões à medida que foram alvos de proteções internacionais e constitucionais de forma cumulativa e não substitutiva.
} 
tratado como ciência, não admite essa condição, pelo menos em nossa grade curricular brasileira. Assim, esse direito tem uma conotação de direito material inserido na lista dos direitos fundamentais humanos, na vertente social, vinculado estreitamente ao Direito ao Desenvolvimento, que pressupõe a efetividade de direitos sociais, econômicos e culturais (SENGUPTA, 2002, pp. 70 e 82) ${ }^{9}$, tendo núcleo central a liberdade de escolha. Esse também será o padrão de desenvolvimento abordado por Amartya Sem, conforme segue abaixo e que será abordado mais a vagar em item próprio:

A expansão da liberdade é vista, por essa abordagem, como o principal fim e o principal meio de desenvolvimento. O desenvolvimento consiste na eliminação de privações de liberdade que limitam as escolhas e as oportunidades das pessoas de exercer ponderadamente sua condição de agente. A eliminação de privação de liberdades substanciais, argumentase aqui, é constitutiva do desenvolvimento. [...] A importância intrínseca da liberdade humana em geral, como objetivo supremo do desenvolvimento, é acentuadamente suplementada pela eficácia instrumental de liberdades específicas na promoção de liberdades de outros tipos. Os encadeamentos entre diferentes formas de liberdade são empíricos e causais, e não constitutivos e compositivos. Por exemplo, há fortes indícios de que as liberdades econômicas e políticas se reforçam mutuamente, em vez de serem contrárias umas às outras (como às vezes se pensa). Analogamente, oportunidades sociais de educação e assistência médica, que podem requerer a ação pública, complementam oportunidades individuais de participação econômica e política e também favorecem nossas iniciativas para vencer privações. [...] o crescimento econômico não pode sensatamente ser considerado um fim em si mesmo. O desenvolvimento tem de estar relacionado, sobretudo com a melhora da vida que levamos e das liberdades que desfrutamos. Expandir as liberdades que temos razão para valorizar não só torna a nossa vida mais rica e mais desimpedida, mas também permite que sejamos seres sociais mais completos, pondo em prática nossas volições, interagindo com o mundo em que vivemos e influenciando esse mundo. (SEN, 2010, pp. 10 e 29).

O Direito à Cidade, assim, pode ser considerado um direito complexo, que aglutina a fruição de todos os direitos sociais, econômicos e culturais em sua amplitude, tendo como fundamento a liberdade que, por sua vez, é pressuposto do Direito ao Desenvolvimento. O fim do Direito à Cidade é o Direito ao Desenvolvimento.

\footnotetext{
${ }^{9}$ Arjun Sengupta afirma que o Comitê dos Direitos Econômicos, Sociais e Culturais examinou o direito à (adequada) moradia e declarou que o mesmo deveria ser visto como o direito em algum local em segurança, paz e dignidade. Isso deveria ser assegurado a todas as pessoas, independentemente de renda ou disponibilidade de recursos econômicos. Porém, Arjun Sengupta ainda complementa essa visão inicial do CDESC, dispondo que, para melhor se alocar como um direito ao desenvolvimento, o tal direito à moradia adequada teria que pressupor a liberdade de escolha, consubstanciada na participação na decisão sobre o local tido seguro.
} 
Aqui, pelos anos de 1980, no contexto da crise do Estado de Bem-Estar, a ideia de desenvolvimento avança das políticas econômicas de cooperação, para se importar com o indivíduo, entendido como efetivo participante do processo plural de desenvolvimento através da distribuição/fruição de forma equitativa e justa dos recursos advindos das políticas de efetivação dos DESC, conforme previsto na Declaração sobre o Direito ao Desenvolvimento da ONU (ONU, 1986). Nesse viés, reside a transfiguração do desenvolvimento, antes ligado aos aspectos economicistas, para o compromisso de bem-estar individual e coletivo, como encarado, nos termos da Declaração, como direito do indivíduo e dos povos (direito humano), podendo ser capitulado como um direito econômico, e posteriormente percebido como direito humano, orientado à consecução desse desenvolvimento em áreas plurais constantes dos DESC, porém com foco em sua efetividade real, tendo, nessa última perspectiva, o Estado como importante promotor, porém não é o único a figurar nessa relação.

O desenvolvimentismo seria considerado um "projeto singular e sequencial de crescimento ou acumulação de riquezas para posterior distribuição" contrapondo-se à noção já apresentada de desenvolvimento que importa em um processo plural de maximização de fruição de DESC e de capacidade com vistas a uma "imediata distribuição das riquezas" (FEITOSA, 2013, p. 224). (grifo nosso).

Nessa conjuntura, exsurge o Direito à Cidade atrelado ao processo de urbanização, no sentido de que esse processo precisa estar vinculado coerentemente com os "desejos do coração", na visão romantizada de Park e de seu cidadão, como defende Sant'anna (2003, p. 93), em especial por ser o lugar onde esse cidadão poderá viver até o fim de seus dias. Destarte, o Direito à Cidade pode ser visto como um direito coletivo de usufruir dos recursos urbanos à disposição de seus moradores e, para além disso, como um direito de reinventar, modificar e alterar a cidade e o próprio cidadão, segundo padrões de necessidade e prioridade coletivamente designados. Evidencia-se, assim, o papel de destaque e relevância da figura do cidadão/morador, elemento central desse direito.

Deveras, a partir das considerações expostas é possível afirmar a inegável vinculação do Direito à Cidade com os direitos econômicos, sociais e culturais previstos no Pacto Internacional dos Direitos Econômicos, Sociais e Culturais das Nações Unidas (PIDESC), tendo como ponto de conexão o direito ao usufruto dos direitos referidos na esfera urbana. O desenvolvimento é um processo econômico, social, cultural e político abrangente, que visa ao bem-estar das pessoas através de sua participação/gozo de tais direitos de forma equitativa e holística. A cidade é o centro dessa realização de bem-estar e desenvolvimento. Consentâneo disso é o interesse 
investigativo - e, por que não, fiscalizatório e denunciativo - pelos processos de urbanização contemporâneos aliados às políticas públicas, entrelaçados pelos ideais neoliberais capitalistas e os grupos/setores econômicos que atuam menos altruisticamente, guiados pelo interesse comum e focados nos resultados que podem advir de uma política urbanística em larga escala.

Por sua vez, essa perspectiva também conduz a um vínculo indelével entre o Direito à Cidade e os Direitos do e ao Desenvolvimento ( $\operatorname{DdD}$ e $\left.\operatorname{DaD}^{10}\right)$. Para Feitosa (2013), o Direito do Desenvolvimento abrangeria o sentido político-econômico do desenvolvimento, à luz dos objetivos e necessidades públicas do Estado, no seu mister de atender ao interesse social que administra. Estaria, pois, incluído em uma vertente clássica mais regional, nacional e internacional, com foco nas coletividades, podendo ser encontrado no Direito do Trabalho, da Saúde, da Educação etc., e nos vieses sócio-políticos econômicas desses direitos, com sede constitucional e base no constitucionalismo econômico. Já o Direito ao Desenvolvimento seria um ramo dos Direitos Humanos, abarcando antes os indivíduos e as coletividades, encarado como processo democrático de alta definição em cujo contexto a decisão de desenvolvimento, como os megaprojetos e as megaoperações de engenharia (construções, eletricidade etc.), vai abranger a expressão das comunidades envolvidas, respeitando suas razões, se for o caso, de não-desenvolvimento ${ }^{11}$, por assim dizer. Tem assento nos documentos internacionais de proteção humana e pode ser encontrado no Direito à saúde, à educação, ao trabalho, dentre outros.

O Direito à Cidade, assim, pode ser considerado um direito complexo, que aglutina a fruição de todos os direitos sociais, econômicos e culturais em sua amplitude, tendo como fundamento a liberdade que, por sua vez, é pressuposto do Direito ao Desenvolvimento. Toda essa problemática traz à tona questões relacionadas à liberdade e à felicidade, o que será objeto do tópico a seguir. Afinal, para que(m) são feitas as cidades?

\section{DIREITO À FELICIDADE: ACEPÇÕES E SINERGIAS COM O DIREITO AO DESENVOLVIMENTO E O DIREITO À CIDADE}

As considerações supratranscritas permitem afirmar que o Direito à Cidade - que tem como objeto a cidade e como elemento central o indivíduo/cidadão (e citadino) - visa ao estudo

\footnotetext{
10 Abreviaturas cunhadas por Feitosa (2013), na obra "Direitos Humanos de Solidariedade: Avanços e Impasses".

11 O Butão é o país que optou pelo "não-desenvolvimento" em determinados setores, como será visto ao longo deste artigo.
} 
do espaço urbano e suas implicações socioeconômicas, políticas e culturais, alvejando, em todo caso, a construção de um locus que distribua, pelo menos de forma aproximada, equitativa e qualitativamente, os recursos necessários à fruição de direitos fundamentais, Afirmou-se, também, o necessário liame entre o Direito à Cidade e o Direito ao Desenvolvimento (DaD), contexto que torna possível a abordagem das conexões entre felicidade e desenvolvimento humano.

Com efeito, tanto a felicidade quanto o desenvolvimento são temas multidisciplinares afetos a diversos campos do saber, como música, literatura, antropologia, filosofia, psicologia, política, sociologia, economia e direito. Para o presente artigo, cujo propósito é analisar as interfaces entre felicidade e desenvolvimento tendo como cenário a cidade, interessa destacar a concepção objetiva da felicidade - o que se deduz de sua positivação em ordenamentos jurídicos diversos - e o desenvolvimento enquanto um direito humano, fato reconhecido pela Resolução 41/128 (1986) da Organização das Nações Unidas (ONU).

Dada a intangibilidade do conceito (subjetivo) de felicidade, que indica qualidade ou estado de feliz, satisfação, júbilo, contentamento, boa fortuna e sorte (HOUAISS; VILLAR, 2009), a visão objetiva da felicidade aproxima-se do bem-estar comum. Para Aristóteles (1984), a felicidade seria o fim da natureza humana: toda ação humana seria orientada para um determinado fim, um bem supremo (summum bonum). Essa finalidade suprema seria a felicidade (eudaimonia), alcançada através da vida virtuosa ${ }^{12}$. A reflexão aristotélica sobre a conduta humana e a busca da felicidade suplanta o viés individual e alcança o coletivo, uma vez que o homem, para o filósofo em comento, é um ser político cujas ações devem visar ao bem comum. A felicidade, assim, configurar-se-ia em meta indiscutível, objetivo definitivo e desejo último dos seres humanos, que seriam responsáveis por buscá-la através de suas condutas.

Os iluministas defendiam a felicidade como algo a que todo ser humano poderia aspirar nesta vida, um direito humano natural atingível, uma meta terrena que surgiu como ideal motivador com o estouro das revoluções norte-americana e francesa (McMAHON, 2006), sendo encarado de forma mais racional a partir da era Moderna. Hobbes (2008), com sua concepção pessimista sobre o homem no estado de natureza ("o homem é o lobo do homem"), reforçou o papel político do Estado em garantir a segurança e o cumprimento dos pactos (leis), visando ao bem comum (felicidade). Locke (2000) defendeu a busca da felicidade (pública) como fundamento da liberdade e das regras morais, cabendo ao Estado o papel de proteção ao tripé

\footnotetext{
12 Virtude aristotélica como justa medida, justo meio entre os extremos, prudência e uso da razão.
} 
vida, liberdade e propriedade; influenciou, assim, a Declaração da Independência Americana, que acabou por incluir a busca da felicidade como direito inalienável. Rousseau (2001) afirmou que o homem é bom por natureza, mas a sociedade o corrompe; o progresso e o mundo civilizado seriam causas da desigualdade (gerando infelicidade), de maneira que o contrato social surgiu como teoria para justificar a submissão de todos à autoridade da lei (Estado) para a construção de uma sociedade harmoniosa baseada na liberdade e voltada ao bem comum.

A doutrina utilitarista, fundada por Bentham (1996, apud SANDEL, 2011) e seguida por Mill (1989, apud SANDEL, 2011), tinha como princípio a maximização da felicidade ou da utilidade $^{13}$. Os utilitaristas defendiam uma ciência da moralidade baseada na medição, agregação e cálculo da felicidade, trabalhando com perspectivas de custo/benefício. Partindo da lógica de que todo ser humano gosta do prazer e detesta a dor, os legisladores deveriam levar isso em conta ao decidir que leis promulgar, assim como o governo, ao definir as políticas públicas a implementar, visando sempre a agir de modo a maximizar a felicidade como um todo. As ideias utilitaristas refletiram no pensamento de políticos, economistas, empresários e cidadãos comuns. O mérito do utilitarismo consiste no nítido intuito de promoção do bem-estar geral, mediante escolhas adequadas e resolução dos problemas que reduzem a utilidade social. Seu demérito reside no fato de que a preocupação com a simples soma das satisfações pode ensejar o desrespeito a direitos individuais, preteridos em nome de uma felicidade geral ${ }^{14}$.

A acepção contemporânea de felicidade merece ser apreciada sob a égide da intitulada Modernidade Líquida de Baumann (2001). Em alusão à metamorfose social que avança em vários sentidos, através de constantes mudanças que não se fixam no espaço nem se prendem ao tempo, o autor faz uso do adjetivo "líquido" como metáfora para caracterizar a fluidez e a inconstância dos valores da sociedade pós-moderna. Seu pensamento crítico chama a atenção para a dissolução ("derretimento") de pontos de referência e estabilidade outrora existentes ("sólidos") que asseguravam certo direcionamento para a construção individual da vida; para a busca frenética de identidade em detrimento de uma vida coletiva; e para a liberdade consumidora que proporciona aos indivíduos a ilusão de felicidade.

\footnotetext{
${ }^{13}$ A utilidade é tida como aquilo que produz prazer ou felicidade e evita dor ou sofrimento.

${ }^{14}$ Para ilustrar essa assertiva, merecem citação dois projetos de Bentham (1996, apud SANDEL, 2011) que representam a lógica utilitarista: (i) o Panóptico, uma prisão com torre de vigia central que permitiria ao supervisor observar os reclusos sem que eles os vissem, sendo administrado por uma empresa privada em troca de lucros do trabalho dos presos, que trabalhariam 16 horas por dia; (ii) a gestão de indigentes, que consistiria em juntar os mendigos em um asilo para pobres autofinanciado, para reduzir sua presença nas ruas, já que encontrá-los perambulando reduziria a felicidade do público em geral, fosse nas pessoas de bom coração, que ficariam comovidas, ou nas insensíveis, que sentiram repugnância.
} 
As correlações entre felicidade e consumismo são fortes no nosso século, moldadas como referenciado no tópico anterior - pelas interferências do capitalismo no processo de urbanização em larga escala, as quais refletem no estilo de vida (e gozo de direitos sociais) da população. O consumismo de hoje não se justifica somente pela satisfação das necessidades, mas pelo desejo de consumir, até como forma de compensação e de ilusória compra de felicidade. O problema é que uma das consequências em manter a busca da felicidade atrelada ao consumo é tornar essa busca interminável, e a felicidade, inatingível.

Nessa situação, o compromisso de um Estado com políticas públicas voltadas à efetivação de direitos fundamentais revela-se essencial. A positivação jurídica da felicidade em documentos de salutar importância para a consagração desses direitos ratifica esse papel estatal, como as declarações setecentistas e algumas constituições.

A Declaração de Direitos da Virgínia (1776), em seu artigo 1ํ, afirma que todos os homens nascem iguais, livres e independentes e possuem direitos certos, essenciais naturais, dos quais não podem abdicar. Esses direitos seriam "gozar a vida e a liberdade com os meios de adquirir e possuir propriedades, de procurar obter a felicidade e a segurança". Por sua vez, a Declaração da Independência Americana (1776) torna inalienável o direito à procura da felicidade, ao passo que a Declaração dos Direitos do Homem e do Cidadão (1789) prevê que "as reivindicações dos cidadãos, doravante fundadas em princípios simples e incontestáveis, se dirijam sempre à conservação da Constituição e à felicidade geral", reforçando a ideia de uma felicidade coletiva.

Em 2011, a ONU, através da Resolução 65/309, intitulada "Felicidade: um enfoque holístico pelo desenvolvimento", apontou a busca da felicidade como objetivo humano fundamental e um dos objetivos de desenvolvimento do milênio, estimulando, assim, a adoção de políticas públicas voltadas a esse desiderato.

O preâmbulo da Constituição da França (1958) reafirma direitos e liberdades da Declaração de 1789 e faz uma explícita adesão aos direitos humanos, dentre os quais a felicidade geral estaria incluída. Já as Constituições do Japão (1947), da Coreia do Sul (1948) e do Butão (2008) atrelam o direito à busca da felicidade ao dever do Estado em promover as condições necessárias para tanto. Nesse sentido, o artigo 13 da Constituição japonesa aduz que o direito à busca pela felicidade, "contanto que não interfira ao bem-estar público comum", será de "suprema consideração na legislação e em outras instâncias governamentais". A Constituição sul-coreana impõe no artigo 10 a "felicidade como um direito de todos", cabendo ao Estado o dever em assegurar os direitos humanos; e a Constituição butanesa destaca no 
preâmbulo o comprometimento do Estado com a felicidade permanente e o bem-estar das pessoas, positivando a Felicidade Interna Bruta (FIB) como índice apto a medir a felicidade geral da população, além de incluir a busca da felicidade como um dos princípios que regem o Estado.

No Brasil, não há menção expressa do direito à busca da felicidade no texto da Carta Magna, mas tramita no Senado Federal uma Proposta de Emenda Constitucional, a PEC 19/2010, de autoria do senador Cristovam Buarque (2010), visando a alterar o artigo 60 para considerar os direitos ali previstos como direitos sociais essenciais à busca da felicidade ${ }^{15}$. Buarque (2014) aduz que a positivação desse direito "humaniza a política", pois a definição dos direitos sociais como essenciais à busca da felicidade permitirá que o desempenho da sociedade brasileira deixe de ser feito apenas com base na renda per capita (PIB), conciliando, assim, direitos sociais e políticos ao sentimento emocional. Para desfazer o equívoco de interpretação de sua proposta, qual seja, a ideia disseminada de que a PEC asseguraria o direito à felicidade subjetiva, Buarque (2014) argui que o propósito é firmar o dever do Estado em oferecer as condições para facilitar a busca da felicidade, destacando que o papel do dirigente político é eliminar os entraves à persecução dessa finalidade:

Felicidade é uma questão pessoal, mas o caminho para ela depende do entorno social onde a pessoa vive; e esse entorno é construído ou desconstruído pela política, pela família, cidade, país e até mesmo pelo mundo. Por isto, o caminho para a busca da felicidade pessoal depende das políticas que administram a sociedade. [Grifos apostos]

$\mathrm{Na}$ justificação da PEC, declara que a busca individual pela felicidade pressupõe a observância da felicidade coletiva, que se configura quando são observados de forma adequada itens que tornam mais feliz a sociedade - justamente os direitos sociais - porquanto uma sociedade mais feliz é aquela mais desenvolvida no sentido de que todos tenham acesso aos básicos serviços públicos de saúde, educação, previdência, cultura e lazer. A pretensa alteração do texto constitucional não visa a autorizar um indivíduo a requerer do Estado ou de um particular providências egoísticas a pretexto de atender à sua felicidade, já que esse tipo de "patologia" não é alcançado pela proposta de inclusão de felicidade como objetivo do Estado (BRASIL, PEC 19/2010).

\footnotetext{
${ }^{15} \mathrm{~A}$ atual redação desse dispositivo versa: "São direitos sociais a educação, a saúde, a alimentação, o trabalho, a moradia, o lazer, a segurança, a previdência social, a proteção à maternidade e à infância, a assistência aos desamparados, na forma desta Constituição". Se a PEC for aprovada, passará a ser: "São direitos sociais, essenciais à busca da felicidade, a educação, a saúde, a alimentação, o trabalho [...]".
} 
Como se observa, a positivação jurídica da felicidade consagra a busca da felicidade como um direito inalienável vinculado ao dever do Estado de promover as condições necessárias para atingir esse desiderato, reforçando, assim, a ideia de uma felicidade coletiva. Nesse diapasão, a felicidade, embora seja subjetivamente sentida, revela-se um bem público tutelado juridicamente. Essa perspectiva encontra-se em forte sinergia com o Direito ao Desenvolvimento $(\mathrm{DaD})$ já mencionado, considerando que desenvolvimento não se traduz apenas em crescimento econômico, mas se relaciona ao grau de satisfação das necessidades humanas.

A inserção da satisfação das necessidades humanas como uma das dimensões do desenvolvimento amplia o olhar acerca desse processo, tornando-o plural. A escolha de um sistema de valores norteando o processo de desenvolvimento coloca o homem no centro das discussões, o que se coaduna com temática da felicidade - coletiva - enquanto indicador de desenvolvimento humano. O aumento da eficácia produtiva, comumente apresentada como fator principal de progresso, não é condição suficiente para o bem-estar da população. Aplicando esse raciocínio à questão da cidade, a urbanização desordenada (ou ordenada sobremodo com foco economicista de reaplicação e reinvestimento de lucros) não viabiliza satisfatoriamente a efetivação de direitos sociais. A estruturação da cidade necessita estar vinculada a esse desiderato; o Direito à Cidade pressupõe uma verdadeira humanização dos processos de urbanização.

É imperioso, assim, enfrentar o desenvolvimento como um processo de expansão das liberdades ${ }^{16}$ de que as pessoas desfrutam, tese defendida por Sen (2000), já que o debate das relações entre felicidade e desenvolvimento social só tem sentido no âmbito dessa formulação múltipla. Defendendo uma economia do bem-estar social, Sen (2000) alega que a expansão das liberdades é o principal fim e o principal meio do desenvolvimento, salientando que a perspectiva baseada na liberdade apresenta uma semelhança genérica à preocupação comum com a qualidade de vida, com o modo como as pessoas vivem e as escolhas que possuem, e não somente com os recursos ou rendas de que dispõem.

Dessa maneira, Sen (2000) conclui que o desenvolvimento requer a eliminação das privações de liberdade - pobreza, tirania, carência de oportunidades econômicas e sociais, negligência dos serviços públicos e intolerância ou interferência excessiva de Estados

\footnotetext{
${ }^{16}$ As liberdades reais, substantivas ou instrumentais elencadas por Sen (2000) relacionam-se às seguintes perspectivas: (i) facilidades econômicas; (ii) liberdades políticas; (iii) oportunidades sociais; (iv) garantias de transparência; e (v) segurança protetora.
} 
repressivos - que limitam as escolhas e oportunidades das pessoas, porquanto a eliminação de tais privações é constitutiva do desenvolvimento. O desenvolvimento vinculado ao aumento das liberdades também possibilita ampliar as capacidades conferidas aos seres humanos; a avaliação do desenvolvimento a partir desse viés permite sua análise como indicativo de bemestar social e guia para políticas públicas a serem implementadas no locus onde esses sujeitos vivem: a cidade.

Cada vez mais, debate-se a relação entre rendas e realizações no intuito de avaliar a qualidade de vida das pessoas, o que está intrinsecamente ligado ao bem-estar, à felicidade coletiva, ao Direito à Cidade. O aumento da renda e da riqueza só tem sentido em face da utilidade desses fatores, das possibilidades conferidas aos destinatários; a simples maximização da riqueza e o mero crescimento econômico são insuficientes para apreciar os fins e os meios do desenvolvimento. No discurso dominante relativo a questões econômicas contemporâneas, "a felicidade da vida humana tem sido frequentemente tratada com desprezo", pois, embora na maior parte do mundo as pessoas tenham se tornado mais ricas, nem por isso são hoje muito mais felizes do que o eram antes, enfatiza Sen (2009).

Com base em tudo o que foi exposto, pode-se afirmar que índices de medição do desenvolvimento calcados tão somente na dimensão econômica, na soma de tudo o que é produzido (e consumido), como o Produto Interno Bruto (PIB), revelam-se limitados na medida em que desconsideram desigualdades e sustentabilidades. Desde 1993, o Programa das Nações Unidas para o Desenvolvimento (PNUD, 2014) passou a utilizar o Índice de Desenvolvimento Humano (IDH) ${ }^{17}$ para mensurar o grau de desenvolvimento dos países então classificados como "desenvolvidos", "em desenvolvimento' e "subdesenvolvidos", desviando o foco da economia para auferir indicadores como expectativa de vida, renda e educação. O IDH também não está livre de críticas, pois peca por não levar em conta efeitos colaterais do progresso como poluição, desagregação familiar e aumento da criminalidade.

Sem a pretensão de afastar os indicadores do desenvolvimento acima referidos, o índice denominado de "Felicidade Interna Bruta" (FIB), idealizado no Butão em 1972 pelo rei Jigme Singye Wangchuck ${ }^{18}$ (FIB, 2014), funda-se na premissa de que o objetivo principal de uma sociedade não deve ser somente o crescimento econômico, mas a integração com o

17 Economistas como Sen (2000) e Mahbub ul Haq (apud FEITOSA, 2013) foram idealizadores desse índice.

${ }^{18} \mathrm{~A}$ título de curiosidade, à época da elaboração do FIB o rei do Butão, que tinha apenas dezessete anos de idade, justificou que "A Felicidade Interna Bruta é mais importante que o Produto Interno Bruto" (FIB, 2014), em resposta aos baixos índices econômicos do país, em termos de renda per capita. 
desenvolvimento material, psicológico, cultural e espiritual. O FIB estrutura-se em nove dimensões, cada uma com diversos indicadores que são avaliados a partir de um questionário elaborado pelo Centro de Estudos do Butão e aplicado à população. A avaliação dos resultados daí decorrentes direciona as políticas públicas e os investimentos econômicos desse longínquo país encravado nas montanhas do Himalaia. Eis os pilares do FIB (LOES, 2014; FIB, 2014):

(i) Bem-estar psicológico: dimensão que avalia a satisfação e o otimismo em relação à própria vida, mediante indicadores que analisam autoestima, percepção de competência, estresse e atividades espirituais; (ii) Saúde: as questões são direcionadas para medir padrões de comportamento arriscados, frequência de exercícios físicos, regime de sono e hábitos alimentares;

(iii) Uso do tempo: um dos pilares mais importantes para medir qualidade de vida, mensura a divisão que cada um faz do tempo no cotidiano, incluídos nesse cálculo as horas dedicadas à educação, trabalho, lazer e até aquelas perdidas no trânsito;

(iv) Vitalidade comunitária: indicador que examina a sensação de acolhimento e vigor dos laços afetivos, a segurança na comunidade, a disposição para a doação e o trabalho voluntário;

(v) Educação: pilar que valoriza a educação formal e informal, o envolvimento na educação dos filhos, as taxas de alfabetização, capacidade de compreensão e conhecimento das tradições;

(vi) Cultura: avalia a participação em eventos culturais e as oportunidades de desenvolvimento das capacidades artísticas, investigando ainda discriminações por raça, gênero e religião e estimulando o conhecimento da cultura local;

(vii) Meio ambiente: esse indicador mede a percepção da qualidade de recursos naturais como água, ar, solo, biodiversidade e acesso a áreas verdes;

(ix) Governança: a imagem de que os cidadãos possuem do governo e a percepção de como as instituições públicas lidam com suas atribuições, incluindo segurança, transparência, acesso à Justiça e nível de envolvimento dos cidadãos, são fatores mensurados nessa dimensão;

(x) Padrão de vida: a investigação sobre o padrão de vida considera renda, segurança financeira, nível de endividamento, qualidade de aquisições dos bens de consumo e gastos com lazer.

As dimensões do FIB, portanto, orientam a construção dos questionários contendo perguntas que abordam circunstâncias diversas da vida dos cidadãos. Esse método vem conquistando adeptos ao redor do mundo ${ }^{19}$, tanto na esfera pública como no âmbito das organizações não governamentais e empresas privadas, por trazer a felicidade pautada na qualidade de vida como indicador de desenvolvimento.

Sob o impacto do FIB, o Brasil, através da Fundação Getúlio Vargas (FGV), está desenvolvendo desde 2013 estudos para o seu primeiro índice de bem-estar apto a mensurar a

\footnotetext{
${ }^{19}$ Canadá, Estados Unidos e Reino Unido são países que aplicam o FIB, segundo dados coletados por Lustosa e Melo (2014).
} 
percepção de felicidade do brasileiro. Batizado de "Well Being Brazil" (WBB), possui dez indicadores: clima e atividades ao ar livre; transporte e mobilidade; família; redes de relacionamento; profissão e dinheiro; educação; governo; saúde; segurança; e consumo. O projeto, gerado no Núcleo de Estudos da Felicidade e do Comportamento Financeiro da FGV, que firmou convênio com a Frente Nacional de Prefeitos (FNP), intenta aferir os indicadores em bairros de cidades do país, para que os resultados possam influenciar decisões do poder público e da iniciativa privada. A ideia é aplicar questionários iniciais através das redes sociais e possivelmente por meio de recenseadores, além de incitar discussões em audiências públicas (MOTA, 2013).

Por outro lado, iniciativas para a aplicação do FIB no Brasil ocorrem desde 2008, a exemplo dos projetos-piloto nas cidades de Angatuba e Itapetininga, ambas no interior de São Paulo (LUSTOSA; MELO, 2014). Em Campinas/SP, no bairro Jardim Campo Belo, região de Viracopos, o projeto foi conduzido por uma organização não governamental, o Instituto Visão Futuro (2009), e realizado em parceira com a Unicamp. As atividades envolveram programas direcionados a crianças (compartilhamento lúdico de valores como generosidade, compaixão, tolerância, serviços e gratidão, exercícios físicos e mentais, saúde preventiva e controle emocional) e jovens (capacitação para a coleta de dados referentes aos questionários do FIB, treinamento para falar em público e desenvolver a autoestima, discussões sobre cidadania e responsabilidade social); aperfeiçoamento e adequação dos questionários pelos professores da Unicamp e aplicação aos moradores de Campo Belo, com posterior divulgação dos resultados (inclusive estatísticos) para debater ações práticas baseadas nas necessidades reveladas pela pesquisa.

Na cidade de Lavras/MG também foi desenvolvida uma pesquisa para a aplicação do FIB, visando a "avaliar se aspectos como sexo, idade, escolaridade e localização geográfica podem implicar em diferentes níveis de felicidade dos indivíduos" (SALES, 2012). Os resultados obtidos apontaram níveis distintos de felicidade de acordo com os indicadores supracitados. No sítio da Secretaria de Planejamento do Estado de Goiás, consta o trabalho de Lustosa e Melo (2014) acerca da Felicidade Interna Bruta como índice de desenvolvimento sustentável, denotando a disseminação da ideia perante o setor público.

Na esfera privada, a empresa Icatu-Hartford, administradora de fundos de investimento e planos de previdência, foi uma das primeiras a adaptar o questionário baseado nas premissas do FIB, baseando-se em quatro pilares conceituais: corpo, mente, bolso e mundo (LOES, 2014). Outro destaque é a empresa Natura, primeira empresa no mundo a trabalhar com o conceito 
de "FIB empresarial", potencializando a atuação da responsabilidade socioambiental no setor privado com a proposta de aumento do bem-estar (LUSTOSA; MELO, 2014).

Destarte, pode-se afirmar que a utilização e averiguação do fator felicidade como elemento indicativo de desenvolvimento social exige uma metodologia própria adequada para possibilitar o alcance de resultados que permitam ações concretas. As relações entre direito, felicidade e políticas públicas estão cada vez mais próximas, e a conscientização sobre essa perspectiva, bem como a concretização dessa necessária interação, tem grandes chances de fomentar o desenvolvimento social para além dos índices de crescimento econômico ou mero desenvolvimentismo, como comprovam os casos das cidades analisadas no tópico a seguir.

\section{CORRELAÇÕES ENTRE DIREITO À CIDADE E DIREITO À FELICIDADE: INDICADORES EMPÍRICOS}

Delineadas as interfaces entre o Direito à Cidade, desenvolvimento, liberdade e felicidade, é de grande relevância trazer dados empíricos que demonstram, clara e objetivamente, a repercussão da efetivação dos Direitos Sociais, Econômicos e Culturais em um dado locus urbano, com consequência na mensuração de seu grau de desenvolvimento e felicidade.

Tomou-se como base dados indicadores de três municípios do Brasil, que se destacam pelos números em áreas como educação, violência, mobilidade, entre outros, os quais servem de fundamento para atestar a qualidade de vida e nível de desenvolvimento de dado espaço urbano. Tais indicadores, por sua vez, são reflexos diretos das opções político-econômicas no que se refere ao processo de urbanização levado a efeito pelos gestores urbanos. Os municípios parâmetros são: São Caetano do Sul-SP, 10 lugar no Ranking de Índice de Desenvolvimento Humano Municipal; Feliz-RS, que ocupa o 551일 lugar no ranking referido e que se destaca pelo elevado nível de qualidade de vida; por fim, Melgaço-PA, que ocupa o último lugar no IDHM pelo Atlas Pnud 2013. O objetivo foi tomar municípios referenciais que ocupam diferenciados lugares no ranking de IDHM a fim de analisar seus indicadores e, em consequência, a relação causal da fruição dos DESC para a mensuração do nível de desenvolvimento e felicidade.

Os indicadores foram relativos à: população, PIB, IDH municipal, IDHM de renda ${ }^{20}$, Fundo de Participação dos Municípios, taxa de analfabetismo, IDHM de educação, taxa de

\footnotetext{
20 O objetivo da criação do Índice de Desenvolvimento Humano foi o de oferecer um contraponto a outro indicador muito utilizado, o Produto Interno Bruto (PIB) per capita, que considera apenas a dimensão econômica do desenvolvimento. Criado por Mahbub ul Haq com a colaboração do economista indiano
} 
mortalidade infantil, violência, moradia adequada, saneamento básico, mobilidade e inserção das crianças na escola. Tomou-se como base dados divulgados no ano de 2010 no Censo IBGE 2010 e Atlas Pnud 2013.

São Caetano do Sul-SP ${ }^{21}$ faz parte do Grande ABC, na região metropolitana da Grande São Paulo. Tem uma área de $15 \mathrm{~km}^{2}$, foi fundada em 28 de julho de 1877 e emancipada em 24 de outubro de 1948, com destaque em atividades de indústria, comércio e serviços. Destaca-se pelo alto índice de escolaridade e renda per capta e baixo índice de extrema pobreza. Segue seus indicadores:

\begin{tabular}{|c|c|c|}
\hline Indicativo & $\begin{array}{c}\text { No/Percentual } \\
\text { municipal } \\
(100.000 \text { hab.) }\end{array}$ & Média Nacional \\
\hline População total & 149.263 & 190.732 .694 \\
\hline População urbana & 149.263 & 160.925 .792 \\
$(84,37 \%)$ \\
\hline População rural & $100 \%$ & 29.830 .007 \\
\hline PIB per capta & $(15,63 \%)$ \\
\hline Taxa de analfabetismo & - & $19.763,93$ \\
\hline Violência (no de assassinatos no ano) & $73.714,74$ & $9,6 \%$ \\
\hline Moradia adequada (tijolo e madeira) & $1,47 \%$ & 26,2 \\
\hline Saneamento básico (esgoto e fossa) & 8 & $89,5 \%$ \\
\hline tijolo & $100 \%(3)$ & $87,3 \%$ \\
\hline Mobilidade (serviço de transporte público e privado: & esgoto & \\
\hline Ônibus, moto e automóvel x no habitantes) & & \\
\hline
\end{tabular}

Amartya Sen, ganhador do Prêmio Nobel de Economia de 1998, o IDH pretende ser uma medida geral, sintética, do desenvolvimento humano. Apesar de ampliar a perspectiva sobre o desenvolvimento humano, o IDH não abrange todos os aspectos de desenvolvimento e não é uma representação da "felicidade" das pessoas, nem indica "o melhor lugar no mundo para se viver". Democracia, participação, equidade, sustentabilidade são outros dos muitos aspectos do desenvolvimento humano que não são contemplados no IDH. O IDH tem o grande mérito de sintetizar a compreensão do tema e ampliar e fomentar o debate. [...] Publicado pela primeira vez em 1990, o índice é calculado anualmente. Desde 2010, sua série histórica é recalculada devido ao movimento de entrada e saída de países e às adaptações metodológicas, o que possibilita uma análise de tendências. Aos poucos, o IDH tornou-se referência mundial. É um índice-chave dos Objetivos de Desenvolvimento do Milênio das Nações Unidas e, no Brasil, tem sido utilizado pelo governo federal e por administrações regionais através do Índice de Desenvolvimento Humano Municipal (IDH-M).O IDH-M é um ajuste metodológico ao IDH Global, e foi publicado em 1998 (a partir dos dados do Censo de 1970, 1980, 1991) e em 2003 (a partir dos dados do Censo de 2000)". Disponível em: http://www.pnud.org.br/IDH/IDH.aspx?indiceAccordion=0\&li=li_IDH. Acesso em 14 out 2014.

${ }^{21}$ Disponível em: http://www.saocaetanodosul.sp.gov.br/a-cidade.html. Acesso em 14 out 2014.

22 PIB per capta - obtém-se pela divisão do PIB nacional pelo número de habitantes. Deve ser analisado em termos de paridade de poder de compra (PC). Disponível em: http://pt.wikipedia.org/wiki/Produto_interno_bruto\#PIB_per_capita. Acesso em 14 out 2014. 


\begin{tabular}{|c|c|c|}
\hline & 1,26 & 2,94 \\
\hline Crianças na escola & $99,4 \%$ & $77,4 \%$ \\
\hline IDHM de Educação & $0,811(4)$ & 0,715 \\
\hline IDH Municipal & $0,862(5)$ & 0,699 \\
\hline
\end{tabular}

Fontes: IBGE/Censo 2010; Atlas Pnud 2013.

1. As estatísticas não fornecem dados para população rural;

2. Os dados mostram $100 \%$ de moradias construídas de tijolo, não havendo números para quaisquer outras espécies de habitação;

3. Quanto ao saneamento básico, toda a rede é de esgotos, portanto não havendo sistema de fossa;

4. IDHM de educação superior à média nacional. Indicador de nível muito alto;

5. IDHM superior à média nacional. Mensuração de nível muito alto.

Por sua vez, Feliz é um município do Rio Grande do $\mathrm{Sul}^{23}$, localizado entre a região metropolitana, a $80 \mathrm{~km}$ de Porto Alegre, e a região serrana do Estado a $45 \mathrm{~km}$ de Caixas do Sul. É a cidade de destaque no Brasil, não obstante não ocupe os primeiros lugares no ranking do IDHM 2010, por seu alto grau de desenvolvimento e indicadores de escolaridade e violência. Suas atividades econômicas são voltadas às indústrias do setor metal-mecânico, calçadista e moveleiro, não obstante a agricultura tenha importante destaque no cultivo de hortigranjeiros, avicultura, suinocultura e fruticultura, além de comércio e serviços. Segue tabela de indicadores.

\begin{tabular}{|c|c|c|}
\hline Indicativo & $\begin{array}{c}\text { No/Percentual } \\
\text { municipal } \\
(100.000 \text { hab.) }\end{array}$ & Média Nacional \\
\hline População total & 12.359 & 190.732 .694 \\
\hline & 9.416 & 160.925 .792 \\
\hline População urbana & $(76,18 \%)$ & $(84,37 \%)$ \\
\hline População rural & 2.943 & 29.830 .007 \\
\hline PIB per capta & $(23,81 \%)$ & $(15,63 \%)$ \\
\hline Taxa de analfabetismo & $19.105,77$ & $19.763,93$ \\
\hline Violência (no de assassinatos no ano) & $9,37 \%$ & $9,6 \%$ \\
\hline & 1 & 26,2 \\
\hline Moradia adequada (tijolo e madeira) & $91,2 \%(1)$ & \\
\hline & $76,4 \%$ tijolo & $89,5 \%$ \\
\hline Saneamento básico (esgoto e fossa) & $14,8 \%$ madeira & \\
\hline & $98,70 \%(2)$ & \\
\hline
\end{tabular}

${ }^{23}$ Disponível em: http://www.feliz.rs.gov.br/municipio. Acesso em 14 out 2014. 
Mobilidade (serviço de transporte público e privado: ônibus, moto e automóvel $\mathrm{x}$ no habitantes)

Crianças na escola

IDHM de Educação

IDH Municipal

Fontes: IBGE/Censo 2010; Atlas Pnud 2013.

1. As estatísticas mostram números mínimos para outros tipos de habitação, tidos irrelevantes;

2. Quanto ao saneamento básico, $1,3 \%$ apenas da população não é contemplada com esse serviço;

3. IDHM de educação muito próximo ao da média nacional, porém com taxa de analfabetismo abaixo da média nacional. IDHM de educação mensurado de alto nível.

4. IDHM superior à média nacional de nível muito alto.

Por fim, o município de Melgaço-PA ${ }^{24}$, a 250,61 km de Belém-PA, com área de $6.774,018 \mathrm{~km}^{2}$ e fundada em $25 \mathrm{de}$ março de 1962. Economicamente, restringe-se aos setores de agropecuária, indústria e serviços, sendo estes últimos a área determinante. Destaca-se, negativamente, pelo baixíssimo nível de escolaridade, de escolas de nível médio e de matrículas.

\begin{tabular}{|c|c|c|}
\hline Indicativo & $\begin{array}{c}\text { No/Percentual } \\
\text { municipal } \\
(100.000 \text { hab. }\end{array}$ & Média Nacional \\
\hline População total & 24.808 & 190.732 .694 \\
\hline População urbana & 5.503 & 160.925 .792 \\
& $22,18 \%$ & $(84,37 \%)$ \\
\hline População rural & 19.305 & 29.830 .007 \\
\hline PIB per capta & $77,81 \%$ & $(15,63 \%)$ \\
\hline Taxa de analfabetismo & $2.898,27$ & $19.763,93$ \\
\hline Violência (no de assassinatos no ano) & $38,48 \%$ & $9,6 \%$ \\
\hline & $-(1)$ & 26,2 \\
\hline Moradia adequada (tijolo e madeira) & $98,8 \%(2)$ & \\
\hline & $96,6 \%$ madeira & $89,5 \%$ \\
\hline Saneamento básico (esgoto e fossa) & $2,2 \%$ tijolo & \\
\hline Mobilidade (serviço de transporte público e privado: & $17,5 \%(3)$ & $8,9 \%$ fossa \\
\hline Ônibus, moto e automóvel x no habitantes) & $0,6 \%$ esgoto & \\
\hline
\end{tabular}

${ }^{24}$ Disponível em: http://cidades.ibge.gov.br/painel/painel.php?codmun=150450. Acesso em 14 out 2014. 


\begin{tabular}{|c|c|c|}
\hline & $605,07(4)$ & 2,94 \\
\hline Crianças na escola & $50,5 \%$ & $77,4 \%$ \\
\hline IDHM de Educação & $0,207(5)$ & 0,715 \\
\hline IDH Municipal & $0,407(6)$ & 0,699 \\
\hline
\end{tabular}

Fontes: IBGE/Censo 2010; Atlas Pnud 2013.

1. As estatísticas não fornecem dados para a ocorrência de homicídios, o que não indica que sejam inexistentes;

2. A quase que totalidade das moradias são construídas à base de madeira, provavelmente em razão da região em que se situa Melgaço (Amazônia);

3. $82,5 \%$ da população não é contemplada com serviço de saneamento básico;

4. São 605,07 pessoas por veículo, considerado o número de habitantes. Isso significa que o meio de transporte predominante é bicicleta, a pé, ou via barco/canoa;

5. O IDHM de educação é bem inferior à média nacional. Mensurado como de nível muito baixo;

6. O IDHM igualmente é abaixo da média nacional e mensurado como de nível muito baixo, embora tenha evoluído a partir de 0,177 em 1991 até então.

Pelos indicadores de São Caetano do Sul-SP, verifica-se uma população essencialmente urbana. As estatísticas não fornecem dados para população rural, dando a compreender que não há representatividade dessa população. Tal fenômeno se explica pelo grau de urbanização que atingiu o município, cujo processo natural se dá em torno da industrialização que concentra suas atividades no locus urbano. O PIB per capta representa mais de 3,5 vezes que a média nacional, demonstrando um alto padrão de vida. A taxa de analfabetismo é seis vezes menor que a média nacional, representando um percentual muito reduzido da população, de maneira que quase a totalidade é alfabetizada. Baixíssimo índice de violência (homicídio por ano), o que expressa um alto grau de segurança e estabilidade. Não há moradias que não sejam de tijolo, expressando a absoluta adequação da mesma, além de uma cobertura completa (100\%) de sistema de saneamento básico por esgoto e nenhuma fossa. Há uma média de 1,26 pessoas por veículo e apenas $0,6 \%$ das crianças até 15 anos de idade estão fora da escola, de forma que o sistema público e privado de educação tem absorvido quase que a totalidade das crianças. Por esses critérios, entre outros, o IDHM e IDHM de educação de São Caetano do Sul foram mensurados acima da média nacional, inferindo-se um alto padrão e qualidade de vida e alto grau de desenvolvimento e urbanização, pela fruição equitativa dos Direitos Sociais, Econômicos e Culturais. 
Na sequência, o município de Feliz-RS tem $76,18 \%$ de sua população total concentrada na área urbana, enquanto que apenas $23,81 \%$ residem na área rural. Diferentemente de São Caetano do Sul, cuja população é apenas urbana, o município de Feliz encontra-se em desenvolvido estágio de urbanização, porém ainda conserva bem delimitada a zona rural e suas atividades peculiares. Tal fato reduz as tensões próprias de uma urbanização periférica. O PIB per capta está quase ao mesmo nível da média nacional, considerando uma região de população que representa em torno de 0,06 da população total do Brasil. A taxa de analfabetismo é inferior à média nacional e, no quesito violência, verifica-se uma ocorrência equivalente a $4 \%$ da média nacional, o que revela um ambiente de segurança. De $91,2 \%$ de moradias adequadas, destaque-se que $76,4 \%$ são de tijolos e apenas $14,8 \%$ de madeira (espécie comum na região serrana), de maneira que $8,8 \%$ das moradias são inadequadas. Uma média, portanto, acima da nacional. Quanto ao saneamento básico, 98,8\% da população conta com a cobertura de esgoto ou fossa, restando apenas 1,2\% que não são contemplados com o serviço. No quesito mobilidade, há 1,68\% pessoas para um veículo (carro, ônibus ou moto) contra 2,94 pessoas por veículo da média nacional, a representar um município que confere mobilidade adequada aos seus cidadãos. 90,1\% das crianças até 15 anos estão na escola, portanto uma média bem superior à nacional. Esse indicador é de extrema relevância na mensuração do IDH, notadamente da educação, que assumiu índice de 0,658, por um pouco menor que a média nacional $(0,715)$. No entanto, à guisa de conclusão dos indicadores de Feliz, uma análise todos os dados levados em conta, tem-se IDHM superior ao nacional, indicando um adequado padrão de vida urbana.

Por fim, como parâmetro negativo de indicação de desenvolvimento, o município de Melgaço-PA tem uma população urbana que representa apenas 0,002 da população nacional em contraposição a uma população rural que reflete 0,01 \% desta última. A concentração da população na área rural em Melgaço tem, basicamente, dois fundamentos: em um primeiro plano, é resultado do próprio contexto do município, localizado na região amazônica, com preponderância de atividades eminentemente rurícolas; em segundo plano, a concentração na área rural significa um processo de desenvolvimento urbanístico ainda tímido, visto que sua peculiaridade é a industrialização com contornos de urbanização crescente a partir de fruição de direitos socioeconômicos e culturais. Ao contrário dos outros dois municípios, o PIB per capta de Melgaço é quase sete vezes inferior à média nacional, além de uma taxa de analfabetismo 4 vezes menor. Apenas 2,2\% da população tem moradia de tijolo e mais de $96 \%$ habita em casas de madeira, demonstrando a precariedade de condições de habitação. Apenas 
17,5\% da população é servida de saneamento básico, sendo que ínfimos 0,6\% são contemplados com rede de esgotos (em virtude do poder aquisitivo). No que concerne à mobilidade, a proporção é de mais de 605 habitantes por veículo (carro, ônibus ou moto), de maneira que os principais meios de transporte são: através de animais (cavalo), carroça, a pé ou via barco ou canoa, representando o nível de atraso e precariedade na qualidade de vida. Mais da metade das crianças até 15 anos está fora da escola e, portanto, tem-se um IDHM de 0,207\%, três vezes inferior à média nacional, uma repercussão direta, entre outras, da não cobertura de educação. Conclusivamente, tem-se um IDHM de 0,407, refletindo o nível muito baixo, o último lugar no ranking nacional estadual IDHM 2013.

A análise empírica dos três municípios parâmetros vem a reforçar as ideias empreendidas por Amartya Sen (2010, p. 10) no sentido de que o efetivo desenvolvimento envolve o direito à liberdade, e esta, por sua vez, só pode ser galgada a partir do efetivo usufruto de Direitos Sociais, Econômicos e Culturais, que são decisivamente definidores de padrões adequados de qualidade de vida, de cidadania, a ponto de imprimir uma nova concepção de sua própria realidade, podendo ensejar a satisfação e a própria mensuração de felicidade individual, muito embora a metodologia de mensuração do IDH especificamente não utilize critérios que infiram esse indicador. Esse último indicativo não é abstrato e nem utópico, não obstante tenha conteúdo mais fluido. Sua quantificação guarda relação intrínseca e direta exatamente com a disponibilização e efetivação dos DESC (destaque nosso) de modo a ser capaz de transformar a própria condição humana de modo digno e potencialmente promissor a indicar um desenvolvimento humano de padrões adequados.

Nesse sentido, o Programa das Nações Unidas para o Desenvolvimento elaborou o Relatório de Desenvolvimento Humano que, em seu capítulo 9, contempla as "Percepções sobre bem-estar e felicidade individuais" 25 a partir de critérios indicadores subsidiados do próprio IDH (emprego, saúde pessoal (\%), padrão de vida (\%)) que manifestam condições materiais de fruição dos DESC (bem-estar); além de indicadores específicos como satisfação com a vida em geral (de 0 a 10); vida com objetivos (\%), tratamento com respeito e rede de apoio social $(n)$, esses últimos relacionados à felicidade. A amostragem $O$ Brasil ocupa o 73으 lugar no ranking, sendo considerado de desenvolvimento elevado a partir dos dados de IDH e felicidade individual.

25 PNUD. Relatório de desenvolvimento humano 2010. Nova York: PNUD, 2010. Disponível em: http://www.pnud.org.br/HDR/arquivos/RDHglobais/PNUD_HDR_2010.pdf. Acesso em 14 out 2014. 
Os indicadores estatísticos são relevantes na identificação do grau de fruição dos Direitos sociais, econômicos e culturais (DESC) no contexto urbano, servindo também como elemento de verificação de graus de desenvolvimento humano, todavia alguns itens não são mensurados nesse indicador e são igualmente relevantes para a avaliação do desenvolvimento humano e da própria felicidade, a saber: capacitação (liberdade de poder de escolha, aptidão para operar mudanças e transformações), democracia (relação intrínseca com liberdade) e desigualdade (exploração de um grupo por outro).

A análise empírica conduz ao entendimento inequívoco da relação direta, porém não exclusiva, da fruição desses DESC com o grau de desenvolvimento humano no contexto urbano, como pressupostos de acesso e ampliação das próprias liberdades, nestas incluída a possibilidade de escolha do modus vivendi, dos recursos de urbanização ao dispor do cidadão, enfim, de sua atuação proativa como sujeitos de definição de políticas públicas nesse sentido com foco finalístico na felicidade.

Nesse ponto, convergem as concepções de Direito à Cidade e à Felicidade no contexto do desenvolvimento humano integral e ampliado em direção também à extensão de suas liberdades como instrumento e fim do desenvolvimento.

Saliente-se, como referido, que tais indicadores (não constantes do rol de critérios específicos para o IDH) têm relação intrínseca com liberdade e desenvolvimento para além das fronteiras meramente urbanísticas de usufruto de recursos materiais, mas interferem de maneira substancial na análise de que nem sempre o crescimento econômico indica desenvolvimento humano. Esse, de certo, é o ponto crucial em direção às incipientes, porém promissoras, pesquisas e políticas em direção à efetivação e verificação da felicidade, notadamente no espaço urbano.

Enfim, destaca-se a relevância dos fundamentos e políticas públicas concernentes ao Direito à Cidade e à Felicidade, com realização e efetivação de políticas públicas que conduzam a essa realidade de desenvolvimento e satisfação, visto que a pessoa humana deve ser o fim da ação estatal. Em razão disso, o desenvolvimento humano não se restringe apenas à produção e distribuição de bens (DESC sob a forma de recursos urbanísticos), mas sobremaneira, com a ampliação e utilização das capacidades, que envolvem poder de escolha, de mudança da realidade, para subsistência e muito mais (realização pessoal), como um processo de desenvolvimento humano, dialético, dinâmico e participativo. 


\section{CONSIDERAÇÕES FINAIS}

A relação dialética entre Direito à Cidade e à Felicidade e desenvolvimento é indelével. O vínculo integrativo entre esses direitos foca-se, inequivocamente, tanto na necessidade de efetivação de Direitos Sociais, Econômicos e Culturais no contexto, minimamente, urbano, como na liberdade como elemento de promoção e finalístico do desenvolvimento. Nesse viés, o desenvolvimento ascende, como propagado pela própria Declaração sobre o Desenvolvimento das Nações Unidas, à condição de direito humano, plural e em constante expansão. Seus agentes promotores são a felicidade e os DESC efetivados.

Tanto o Direito à Cidade como o Direito à Felicidade trazem como pressupostos a sua efetivação elementos como saúde, educação, meio ambiente, cultura, direitos civis e políticos como requisitos humanos concretamente mensuráveis e que são o elo de vinculação entre os dois direitos. Para além dessa perspectiva concretista, há alguns valores abstratos, subjetivos, ou mesmo fluidos, porém mensuráveis e afetos especificamente à Felicidade, mas que estão indissociavelmente, coligados à própria essência do Direito à Cidade e ao desenvolvimento humano, a saber: bem-estar psicológico, capacitação e vitalidade comunitária, os quais traduzem sentimentos, percepções, sensações, consentâneos por excelência de um padrão de vida digno no locus urbano em virtude da adequada disponibilização e efetivação de DESC.

Essa inferência é refletida, claramente, nos dados empíricos colacionados nesse ensaio, originados do Programa das Nações Unidas para o Desenvolvimento, cuja mensuração do desenvolvimento humano é feita sob duas perspectivas:

1) A partir do nível de fruição de DESC (IDH e IDH-Municipal), notadamente, saúde (expectativa de vida), educação (escolaridade e expectativa de formação futura) e rendimento, como indicadores do padrão de vida afetos aos direitos concretamente mensuráveis a partir de políticas públicas positivas e finalísticas no sentido desse desenvolvimento;

2) A partir de elementos subjacentes (índices medidos em termos percentuais e que não se confundem com o IDH, mas o complementam) aos DESC, mas que têm relação direta na verificação desse desenvolvimento humano, a saber: IDH ajustado à Desigualdade, Índice de Desigualdade de Gênero, Índice de Pobreza Multidimensional, capacitação (liberdade de escolha e de transformação - liberdades civis), Sustentabilidade e Vulnerabilidade, Segurança humana (armas, guerras, alimentação), Percepções sobre bem-estar e felicidade (satisfação, emprego, saúde, apoio), Bem-estar cívico e 
comunitário (homicídios e comunidade), Tendências demográficas, Trabalho digno, Ambiente impulsionador (despesas públicas e assistências para desenvolvimento, economia) e acesso às tecnologias de informação.

Foi dada atenção especial aos IDH e IDH-M, pela magnitude dos critérios e especificidade da temática aqui abordada, e às Percepções sobre bem-estar e felicidade como elementos subjacentes ao IDH para análise do Direito à Cidade e à Felicidade na perspectiva do desenvolvimento. Esses últimos são, assim, considerados como variáveis que potencialmente desmistificam o crescimento econômico e o próprio desenvolvimento como afetos apenas à fruição dos DESC, embora imprescindíveis, requisitam atenção específica aos elementos abstratos que conduzem à percepção de felicidade, notadamente no espaço urbano.

Assim, Direito à Cidade e à Felicidade se complementam como instrumentos de orientação à persecução do desenvolvimento como direito humano inalienável e urgente. O elo entre eles reside no foco à liberdade como pressuposto da capacitação dos indivíduos, atores sociais protagonistas de novos padrões de urbanização e desenvolvimento guiados pela sede de felicidade.

\section{REFERÊNCIAS}

ARISTÓTELES. Ética a Nicômaco. São Paulo: Victor Civita, 1984. Disponível em:<http://sumateologica.files.wordpress.com>. Acesso em: 15 jun. 2014.

BAUMAN, Zygmunt. Modernidade líquida. Rio de Janeiro: Zahar, 2001.

BAVA, Silvio Caccia._Le Monde Diplomatique Brasil. Ano 7. No. 73

BRASIL. Constituição (1988). Constituição da República Federativa do Brasil. São Paulo: Saraiva, 2011.

Proposta de Emenda à Constituição n.o 19, de 2010. Disponível em: <http://www.senado.gov.br>. Acesso em: 16 jul. 2014.

BUARQUE, Cristovam. Felicidade e política. Disponível em:<http://www.lexml.gov.br>. Acesso em: 07 jun. 2014.

CONSTITUIÇÃO DA COREIA DO SUL (1948). Constitution of the Republic of Korea._Disponível em: <http://korea.assembly.go.kr>. Acesso em: 10 jul. 2014.

CONSTITUIÇÃO DA FRANÇA (1958). Constituição da França. Disponível em: <http://www.dhnet.org.br>. Acesso em: 10 jul. 2014. 
CONSTITUIÇÃO DO BUTÃO (2008). The Constitution of the Kingdon of Bhutan._Disponível em: <http://www.bhutanaudit.gov.bt>. Acesso em: 11 jul. 2014.

CONSTITUIÇÃO DO JAPÃO (1947). Constituição do Japão._Disponível em: <http://www.br.embjapan.go.jp>. Acesso em: 10 jul. 2014.

DECLARAÇÃO DA INDEPENDÊNCIA AMERICANA (1776). Declaração de Independência dos Estados Unidos da América._Disponível em: <http://www.humanrights.com>. Acesso em: 10 jul. 2014.

DECLARAÇÃO DOS DIREITOS DA VIRGÍNIA (1776). Declaração dos Direitos da Virgínia_Disponível em: <http://www.dhnet.org.br>. Acesso em: 10 jul. 2014.

DECLARAÇÃO DOS DIREITOS DO HOMEM E DO CIDADÃO (1789). Declaração dos Direitos do Homem e do Cidadão._Disponível em: <http://www.dhnet.org.br>. Acesso em: 10 jul. 2014.

FEITOSA, Maria Luiza Alencar Mayer. Direito econômico do desenvolvimento e direito humano ao desenvolvimento. Limites e confrontações. In: FEITOSA, Maria Luiza Alencar Mayeret al. (orgs.). Direitos humanos de solidariedade: avanços e impasses. Curitiba: Appris, 2013.

FELIZ (Município). Prefeitura municipal de Feliz-RS. Disponível em: http://www.feliz.rs.gov.br/municipio. Acesso em 14 out 2014.

FIB - Felicidade Interna Bruta. 0 que é FIB? Disponível em: <http://www.felicidaadeinternabruta.org.br>. Acesso em: 01 jul. 2014.

HARVEY, David. O direito à cidade. Revista Piauí. Ed. 82, jul/2013. Disponível em: http://revistapiaui.estadao.com.br/edicao-82/tribuna-livre-da-luta-de-classes/o-direito-acidade.

A produção capitalista do espaço. São Paulo: Annablume, 2005.

HOBBES, Thomas. Leviatã: ou a matéria, forma e poder de um estado eclesiástico e civil. São Paulo: Ícone, 2008.

HOUAISS, Antônio; VILLAR, Mauro de Salles. Dicionário Houaiss da Língua Portuguesa. Rio de Janeiro: Objetiva, 2009.

IBGE. Municípios: dados gerais. Disponível em: http://cidades.ibge.gov.br/painel/painel.php?codmun=150450. Acesso em 14 out 2014.

Censo 2010. Disponível em: www.censo2010.ibge.gov.br. Acesso em 14 out 2014.

INSTITUTO VISÃO FUTURO. Descrição do Projeto Campo Belo, Campinas 2009. Disponível em <http://www.visaofuturo.org.br>. Acesso em: 23 jul. 2014.

LEFEVBRE, Henri. O direito à cidade. 5 ed. São Paulo: Centauro, 2005.

LOCKE, Jonh. Ensaio acerca do entendimento humano. Coleção Os Pensadores. São Paulo: Nova Cultural, 2000. 
LOES, João. Qual o seu índice de felicidade? Disponível em: <http://www.istoe.com.br/reportagens/14228>. Acesso em: 16 maio 2014.

LUSTOSA, Alberto Elias; MELO, Lucelena Fátima de. Felicidade Interna Bruta (FIB) - Índice de Desenvolvimento Sustentável. Disponível em:<http://www.seplan.go.gov.br>. Acesso em: 15 jul. 2014.

McMAHON, Darrin M. Felicidade: uma história.São Paulo: Globo, 2006.

MOTA, Camilla Veras. FGV lança índice que calcula percepção de felicidade do brasileiro. Disponível em: <http://www.valor.com.br>. Acesso em: 29 jul. 2014.

ONU - Organização das Nações Unidas. Resolução 41/128 (1986)._Disponível em: <http://www.onu.org.br>. Acesso em: 12 jul. 2014. 2014.

Resolução 65/309 (2011)._Disponível em: <http://www.onu.org.br>. Acesso em: 12 jul.

Declaração sobre Direito ao Desenvolvimento, 1986.

Pacto Internacional sobre Direitos Econômicos, Sociais e Culturais, 1966.

PIOVESAN, Flávia. Direitos Humanos e o Direito Constitucional Internacional. 9 eds. São Paulo: Saraiva, p. 28.

Direitos sociais, econômicos e culturais e direitos civis e políticos. SUR - Revista Internacional dos Direitos Humanos. Ano I, Número I, 2004, p. 22

PNUD. Relatório de desenvolvimento humano 2010. Nova York: PNUD, 2010. Disponível em: http://www.pnud.org.br/HDR/arquivos/RDHglobais/PNUD_HDR_2010.pdf. Acesso em 14 out 2014.

Atlas do desenvolvimento humano dos Municípios. Nova York: PNUD, 2010. Disponível em: http://www.pnud.org.br/HDR/arquivos/RDHglobais/PNUD_HDR_2010.pdf. Acesso em 14 out 2014.

ROUSSEAU, Jean-Jacques. A origem da desigualdade entre os homens. Coleção Grandes Obras do Pensamento Universal 7. São Paulo: Escala,2001.

Do contrato social. Coleção Saraiva de Bolso. São Paulo: Saraiva, 2010.

SALES, Aline Pereira et al. Felicidade Interna Bruta: um estudo na cidade de Lavras - MG. Disponível em: <http://www.anpad.org.br>. Acesso em: 15 jul. 2014.

SANT'ANNA, M. J. G. A concepção de cidade em diferentes matrizes teóricas das ciências sociais. Revista Rio de Janeiro, n.9, 2003, p. 91-99.

SANDEL, Michael J. Justiça: fazemos o que devemos?. Lisboa: Editorial Presença, 2011.

SÃO CAETANO DO SUL (Município). Prefeitura municipal de São Caetano do Sul-SP. Disponível em: http://www.saocaetanodosul.sp.gov.br/a-cidade.html. Acesso em 14 out 2014.

SARLET, Ingo Wolfgang. A eficácia dos direitos fundamentais. 6 eds. Porto Alegre: Livraria do Advogado, 2006 
SEN, Amartya. Desenvolvimento como liberdade. São Paulo: Companhia das Letras, 2000. A ideia de justiça. Coimbra: Almedina, 2009.

SENGUPTA, Arjun. O direito ao desenvolvimento como um direito humano. Social Democracia Brasileira, 2002.

Trabalho enviado em 20 de julho de 2017.

Aceito em 12 de novembro de 2017. 